\title{
Evaluating Aggregate Terrestrial Impacts of Road Construction Projects for Advanced Regional Mitigation
}

\author{
James H. Thorne $\cdot$ Evan H. Girvetz • \\ Michael C. McCoy
}

Received: 27 July 2007/ Accepted: 5 December 2008/Published online: 14 February 2009

(C) The Author(s) 2009. This article is published with open access at Springerlink.com

\begin{abstract}
This study presents a GIS-based database framework used to assess aggregate terrestrial habitat impacts from multiple highway construction projects in California, USA. Transportation planners need such impact assessment tools to effectively address additive biological mitigation obligations. Such assessments can reduce costly delays due to protracted environmental review. This project incorporated the best available statewide natural resource data into early project planning and preliminary environmental assessments for single and multiple highway construction projects, and provides an assessment of the 10-year state-wide mitigation obligations for the California Department of Transportation. Incorporation of these assessments will facilitate early and more strategic identification of mitigation opportunities, for single-project and regional mitigation efforts. The data architecture format uses eight spatial scales: six nested watersheds, counties, and transportation planning districts, which were intersected. This resulted in 8058 map planning units statewide, which were used to summarize all subsequent analyses. Range maps and georeferenced locations of federally and state-listed plants and animals and a 55-class landcover map were spatially intersected with the planning units and
\end{abstract}

\section{J. H. Thorne $(\varangle) \cdot$ M. C. McCoy}

Information Center for the Environment, University

of California, 2132 Wickson Hall, 1 Shields Ave., Davis,

CA 95616, USA

e-mail: jhthorne@ucdavis.edu

M. C. McCoy

e-mail: mcmccoy@ucdavis.edu

E. H. Girvetz

College of Forest Resources, University of Washington,

Box 352100, Seattle, WA 98195-2100, USA

e-mail: girvetz@u.washington.edu the buffered spatial footprint of 967 funded projects. Projected impacts were summarized and output to the database. Queries written in the database can sum expected impacts and provide summaries by individual construction project, or by watershed, county, transportation district or highway. The data architecture allows easy incorporation of new information and results in a tool usable without GIS by a wide variety of agency biologists and planners. The data architecture format would be useful for other types of regional planning.

Keywords Multiscale database - Aggregate impacts . Cumulative mitigation obligations - Road construction . Listed species $\cdot$ Impacted habitats

Road networks have multiple ecological impacts (Forman and others 2003; National Academy of Sciences 2005) and affect about one-fifth of U.S. lands (Forman 2000). Transportation planners challenged with maintaining environmental quality while accommodating transportation needs (Levinson 2004) need effective ways to forecast ecological impacts. This capacity would permit better advanced integration of mitigation actions into regional resource management plans through proactive impact avoidance, streamlining of environmental review, and placement of compensatory offsite mitigation sites so that they support regional conservation goals. The long planning horizon of most transportation agencies for road construction projects provides an opportunity to assess impacts from multiple road construction projects, permitting a compilation of regional habitat impacts (Thorne and others 2006a). This compilation can permit calculation of a transportation agency's cumulative mitigation obligations for a region. Tool development for the accurate projection 
of potential impacts has become an area of great interest to transportation agencies (Brown 2006).

Mitigation for unavoidable road construction impacts has been recommended using regional (Brown 2006) or watershed-scale (National Academy of Sciences 2001) spatial domains. Expanding from project-by-project approaches to impact assessment of multiple road projects offers the possibility of ecologically superior and more economical results by aggregating many small mitigation areas required to target acquisition of larger blocks of habitat (Hardy 2007). These could more easily be selected to support regional conservation plans (Possingham and others 2006; Margules and Pressey 2000; Sarkar and others 2006), permitting mitigation acquisitions that contribute to more effective regional resource management or that better address endangered species needs (Section 10, U.S. Endangered Species Act, U.S. Congress 1973). For U.S. transportation agencies, this approach has been mandated by the Safe, Accountable, Flexible, Efficient Transportation Equity Act (SAFETEA-LU; U.S. Congress 2005), which directs transportation agency planners to adopt regional planning. Aggregated road project impact assessments can also permit streamlining of the environmental review process, because actionable direct environmental impacts, which can be measured at the multisite-scale using landscape-scale data, can be identified. For example, the area of a particular habitat type projected to be impacted across three projects could be summed, permitting identification of the extent needed to satisfy compensatory mitigation required of all three projects. Options for meeting the projected mitigation obligations include habitat acquisition by the agency developing the projects, use of a mitigation bank, and/or restoration of suitable habitat.

Review of potentially significant environmental impacts for proposed transportation projects typically has not occurred until a project receives funding authority, at which point, for the purposes of the National Environmental Policy Act (U.S. Congress 1969), it becomes a "programmed project" subject to environmental review. However, in order to have reached the stage of program funding, a project must be fairly well developed in terms of its engineering requirements. This means that significant investment has already been made in project site selection and design, and the flexibility needed to avoid or minimize environmental impacts may have already been substantially reduced. In these circumstances, compliance-oriented compensatory mitigation (Environmental Law Institute 2006) becomes the only available option for satisfying environmental regulations, and is often a costly and timeconsuming procedure. In addition to forgoing the flexibility to practice avoidance and minimization of impacts at the early planning stage, current practice may rush environmental scoping in the haste to produce projects once funding has been programmed. Making use of regional and early impact assessments by quantifying aggregate impacts could help avoid these pitfalls (Hardy 2007).

In the transportation field, late environmental assessment of road development project impacts is also the primary cause of costly construction delays (American Association of State and Highway Transportation Officials 2003). For example, cost overruns for California Department of Transportation (Caltrans) projects are an estimated $\$ 59$ million per year due to delays caused during environmental review (Byrne 2005). A consortium of United States federal agencies have agreed that regional assessment and planning that permits early environmental impact assessment should be a goal to help guide the development of infrastructure projects (Brown 2006), and U.S. transportation agencies have begun to address the call for regional aggregate road impact assessments. Some statewide examples include projects in Florida (Florida Department of Transportation 2001; Hoctor and others 2000) and the multiple initiatives listed by Brown (2006).

Recognizing the spatial and temporal limitations of project-by-project impact assessment late in the planning process, the California Department of Transportation (Caltrans) has called for the development of early mitigation needs assessment capacity. This capacity would permit mitigation assessments for any programmed project in the state, for a minimum of a 10-year planning horizon, and would permit earlier incorporation of aggregate impact estimates that could be associated with any given set of projects. In particular, Caltrans seeks the capacity to assess summary mitigation needs of its 12 transportation planning districts. There is a desire to know whether or not impacted habitat types are rare, both locally and statewide. Moreover, there is a need to know mitigation needs within different planning units (e.g., watershed or administrative boundaries) across multiple spatial scales (Fig. 1). This multiscale approach to mitigation assessment allows planning and policy questions to be addressed and actions taken at relevant spatial scales.

The utility of a Geographic Information System (GIS) approach for assessing landscape-scale road impacts has been recognized (Treweek and Vietch 1996; Miller 1999), particularly the use of GIS quantitative predictions of habitat impact (Geneletti 2006). GIS analysis permits identification of a footprint, or area extent, for each road project and its associated habitat impacts, permitting quantification of regional habitat impacts from multiple projects. This type of regional assessment can contribute to proactive environmental management (O'Neill and others 1997; Dale and others 2005) by informing systematic mitigation and conservation planning. 
Fig. 1 The database's flexible spatial definition capacity permits generation of standardized reports for greater or smaller areas. By defining a set of possible spatial configurations that combined nested watersheds, counties and transportation districts, tabular output from GIS overlays were portable to a database structure. This structure could then be used in development of queries that produce standardized reports on a wide variety of spatial definitions. Illustrated here are some of the possible reports: statewide, transportation district, and four of the nested watershed scales that can be queried. The Salinas River watershed, reported in the text, is the Hydrologic Unit shown

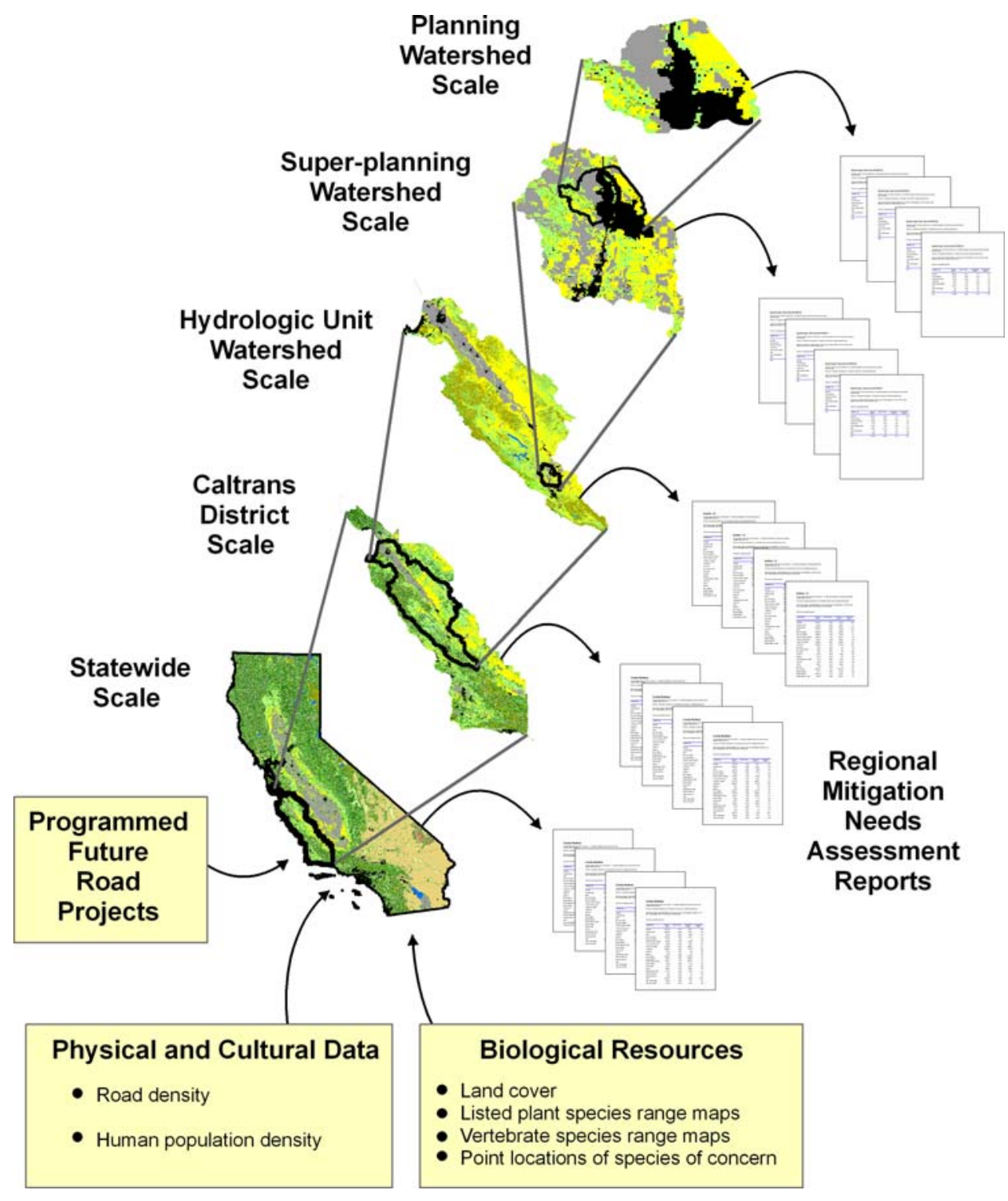

This paper presents an approach to regional mitigation needs assessments that uses a database tool, constructed using GIS, that permits multiscale aggregate habitat impact assessment for single or multiple highway construction projects. The database consists of eight spatial representations of California that were combined to create a single spatial framework. We intersected the best available statewide landcover data, range maps of state and federally listed species, known locations of federally and state listed species, and existing human impacts consisting of roads and population density with the spatial framework. Finally, currently funded (programmed) major highway projects were incorporated to allow for an assessment of biological impacts caused by these projects. We present summary results of the aggregate impacts assessment from programmed Caltrans projects for each of the 12 Caltrans districts. In addition, as demonstration of the flexibility of the database structure, we report aggregate mitigation needs assessments for a single project, a large Central California coastal river watershed, the Salinas River, and for the projects along a single highway, Highway 132.

\section{Methods}

We developed a relational database which permitted the integration of biological, cultural, and infrastructure data. The database was developed by conducting spatial overlays in GIS (ESRI 2006), whose output tables were subsequently incorporated in a Microsoft Access relational database (Microsoft 2006). Key to the study was the spatial framework of the database, which consists of a 
combination of two nested administrative boundary delineations and six nested levels of watershed boundary delineations for the entire state of California (Fig. 1). The administrative boundaries used were Caltrans districts (12 units; California Department of Transportation 2006), and California counties (58 units; California Department of Forestry and Fire Protection 2004). The levels of watersheds used, from largest to smallest size were: river basins (RB; 9 units), hydrologic units (HU; 189 units), hydrologic areas (HA; 578 units), hydrologic subarea (HSA; 1040 units), super planning watersheds (SPWS; 2309 units), and planning watersheds (PWS; 6998 units; California Interagency Watershed Mapping Committee 2004). All boundary delineations were intersected together to create a map containing 8058 unique combinations of district, county, and watersheds, here termed planning units.

Mapped programmed highway construction projects were buffered on each side of their centerline by $500 \mathrm{~m}$ and were intersected with the planning units. This allowed analyses of the biological resources potentially impacted by future highway projects, by summation of the impact areas in various combinations of planning units. The planning units were used to intersect and summarize available biological, physical, and demographic information, which were also put into the relational database for assessing the Caltrans' biological mitigation needs.

\section{Biological Database}

The biological components integrated into the database comprise four elements that were mapped statewide: landcover derived from satellite imagery; point locations of known occurrences of state and federally listed threatened, rare, or endangered species; and species range maps, obtained from two separate data sources for state and federally listed threatened, rare or endangered plants and animals.

We used the California Department of Forestry and Fire Protection's Fire and Resource Assessment Program (FRAP; 2002) multisource GIS landcover of California map, a composite map based on the best available information in various regions with a $100-\mathrm{m}$ raster cell size. It identifies 55 landcover types, termed Wildlife Habitat Relationship (WHR) classes, for $410,000 \mathrm{~km}^{2}$ in California. The FRAP map was used to assess the extent of impacts by proposed projects on different habitat types.

We incorporated two sets of information about species: georeferenced observations and potential occurrences as measured by range maps. The georeferenced observations were obtained from the state's California Natural Diversity Database (CNDDB; California Department Fish and Game, Wildlife and Habitat Data Analysis Branch 2006), a natural heritage database containing reported locations for species of management concern. The terrestrial vertebrate range maps were developed by California Department of Fish and Game (2005) and represent wildlife biologists' handdrawn range maps for all California vertebrates. Vascular plant range maps were derived from the CalJep database (Viers and others 2006), which defines plant ranges by a plant's presence or absence in each of 228 map units in California, and is based on two California floras-the Jepson Manual (Hickman 1993) and the Munz flora (Munz 1968; Munz and Keck 1959). We took the range map for each listed plant, and intersected it with its estimated elevational distribution (Hickman 1993), resulting in a more conservative estimate of the distribution of each plant species. Each species occurrence and range map was intersected with the planning units and buffered programmed projects mentioned above, and resulting tables were input to the database.

\section{Existing Impacts}

A set of summary statistics was calculated for each planning unit, which indicates the level of human activity already present on the landscape. The roads' layer (Geographic Data Technologies 2006) was intersected with the planning units to calculate the length of different types of roads (federal or state highway), in each spatial unit. Similarly, block-level population and the number of homes (U.S. Census Bureau 2000) were broken into each spatial unit. These data provide contextual information about other potential ecological impacts in the area of the programmed highway projects.

\section{Programmed Transportation Project Impacts}

A GIS of programmed (already funded) transportation projects (Fig. 2) was obtained from the California Transportation Investment System (CTIS; Caltrans, unpublished) and used to estimate the potential biological impacts due to each project within the planning units composed of counties, transportation districts, and nested watersheds. The CTIS GIS shows the segments of roads where projects are planned to occur and provides a description of each project. Based on the project description and consultation with Caltrans planners about the average distance affected by various types of road projects, we classified the approximate linear distance from the center of the road that would be impacted by different types of projects (Table 1). The distance impacted ranged from $152 \mathrm{~m}$ for a highway being built on a new alignment to $2 \mathrm{~m}$ for median replacement or traffic operation systems. Sections of road along which more than one project overlapped were flagged so that in subsequent database analyses, these areas were not doublecounted. 


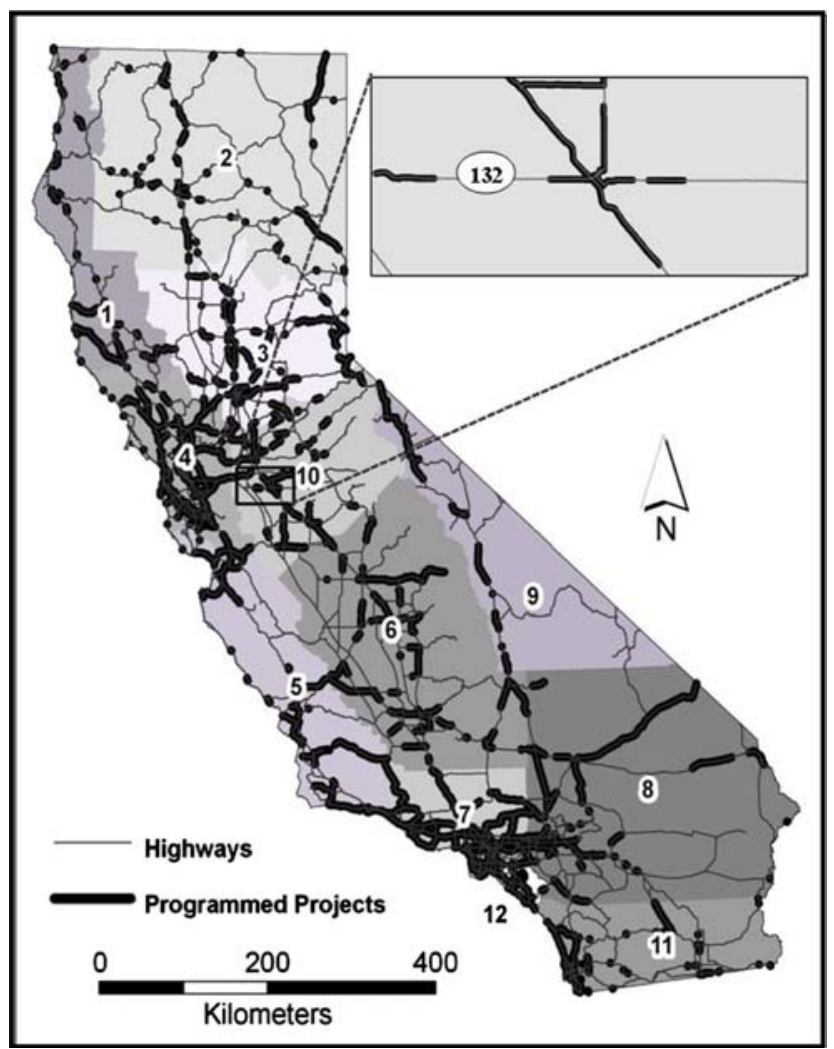

Fig. 2 The 967 programmed projects in California, as derived from the CTIS database. The impacts of each of these were assessed separately and the data complied for report generation from a number of perspectives. Numbers on the map indicate Caltrans Districts. The inset shows projects along Highway 132

To estimate the amount of each habitat type impacted by each programmed project, we buffered each project $500 \mathrm{~m}$ out from the road centerline on either side, and intersected the resulting polygon with the landcover map. We identified the area occupied by, and the percent of, each habitat type within each buffered project. We then calculated the actual area of impact to each habitat type by multiplying the footprint of the project (length of road by distance from centerline impact from Table 1) by the percentage of area occupied by each habitat type in the broader landscape sample. This analysis permitted better identification of all the habitat types surrounding a project, some of which might not have been identified had we used only the estimated impact footprint of the project, because of the disparity of spatial scales between the statewide landcover map and the specific project extent. Since the landcover map has a $100 \mathrm{~m}$ resolution, and a project's impacts could extend only to a maximum of $152 \mathrm{~m}$ from the center of the road, better representation of habitat types potentially found in the impact area was obtained by sampling a wider area and then assuming that the types found would be proportionally present within the footprint of the project being analyzed.
The $500 \mathrm{~m}$ buffers of CTIS projects and the planninglevel watershed boundaries were intersected with the georeferenced observations of threatened and endangered species from the CNDDB. This permitted a list of listed species that had been recorded either in the vicinity of each project or within the watershed(s) each project was in.

To identify listed species that might be found at each CTIS project, the listed vertebrate and plant species range maps were intersected with all of the planning-level watersheds that road projects fell within. This permitted a list of threatened and endangered species that could potentially be on-site because their range intersected a watershed containing all or part of a project. This list represents species that biologists should look for when surveying the site.

Database Assembly and Outputs

Once the spatial processing was complete, the tables representing the intersection results were imported into a relational Microsoft Access database. All the biological data were linked to each highway and programmed road project within each of the planning units. A graphical user interface (GUI; Fig. 3) was developed to allow for queries to be run easily, and a report generating function was created to output standardized reports from the custom queries. Using the GUI, combinations of transportation district, county, watershed, highway, and projects can be queried and potential biological impacts due to programmed transportation projects returned in a standardized report format.

Five standardized reports are available for any given queried area: (1) the extent of different landcover types in the state and selected subregion and the area of each type impacted by all programmed transportation projects based on the project type in the given queried area; (2) a list of the georeferenced listed species occurrences (from the CNDDB) located in the watersheds containing the projects of the queried area, as well as (3) those that were located within $500 \mathrm{~m}$ of the selected programmed projects; (4) a list of the vertebrate species, including listing status, whose range maps overlap with the watersheds containing the projects for the queried area; and (5) a list of the state and federally listed plants, whose range maps overlap the watersheds containing the projects for the queried area. The first page of each report contains background summary contextual information about the queried area including the length of the different types of roads, size of human population, number of houses, number of programmed transportation projects, and publication date of data used for the analysis. Transportation planners in California commonly use areas and distances in acres and miles, so the database can report results in metric or English units. 
Table 1 Footprint width of highway project types in California estimated by Caltrans transportation planners

\begin{tabular}{|c|c|}
\hline Project type & $\begin{array}{l}\text { Estimated footprint } \\
\text { width }(\mathrm{m})\end{array}$ \\
\hline New alignment & 152 \\
\hline Reconstruct interchange and access ramps & 61 \\
\hline Construct expressway & 61 \\
\hline Construct new bridge & 46 \\
\hline Widen roadway & 31 \\
\hline Remove rail trestle & 31 \\
\hline Realign curve & 31 \\
\hline Grade separation improvements & 31 \\
\hline Construct expressway existing alignment & 31 \\
\hline Truck climbing lanes & 15 \\
\hline Slow vehicles lane & 15 \\
\hline Passing lanes & 15 \\
\hline Construct lane & 15 \\
\hline High-occupancy lanes & 12 \\
\hline Stabilize slope & 9 \\
\hline Rehabilitate roadway & 9 \\
\hline Construct noise barrier & 9 \\
\hline Slope erosion control & 9 \\
\hline Construct left-urn lane & 9 \\
\hline Construct bike path & 9 \\
\hline Construct retaining wall & 6 \\
\hline Rehabilitate other & 6 \\
\hline Other project & 6 \\
\hline Install median barrier & 6 \\
\hline Repair landslide & 6 \\
\hline Roadside rest areas & 3 \\
\hline Rehabilitate pavement & 3 \\
\hline Install warning devices & 2 \\
\hline Install message signs/traffic operation systems & 2 \\
\hline Install ramp metering & 2 \\
\hline Operational improvements & 2 \\
\hline
\end{tabular}

\section{Results}

We present mitigation needs results for a single project, the entire state, each of the 12 Caltrans districts, a watershed, and a single highway, to illustrate how projected impacts can be summarized for different study domains.

\section{Single Project}

Project 5-0A4000, selected at random, is a roadway rehabilitation, with an estimated $3 \mathrm{~m}$ impact on each side of the road. The work is scheduled along $8 \mathrm{~km}$ of highway and is projected to traverse 24 ha $(3 \mathrm{~m} \times 8 \mathrm{~km})$, with $52 \%$ of that going through agriculture and $34.6 \%$ through annual grasslands, both types that are extensive within the state and for which mitigation requirements are generally low. The project crosses 0.1 ha of blue oak woodland, a valuable habitat type for wildlife, and impacts 0.3 ha of critical coastal scrub habitat, which is a recognized conservation concern that is home to several endangered species. These fine scale results were derived through the buffered road sampling method and represent the landscape percentage that blue oak and coastal sage scrub occupy within $500 \mathrm{~m}$ of the project's centerline, multiplied by the area of the project footprint.

The range maps of 12 listed vertebrate and 9 listed plant species intersect the planning-level watershed in which the project occurs. These species are potentially present within the footprint of the project but have not been recorded there. The geographic locations of observations of five listed species are recorded within the watershed of the project, and four of those are found within $500 \mathrm{~m}$ of the project: California jewel-flower (Caulanthus californicus), giant kangaroo rat (Dipodomys ingens), blunt-nosed leopard lizard (Gambelia sila), and San Joaquin kit fox (Vulpes macrotis mutica).

Statewide and Caltrans District Aggregate Impacts

Of the 967 programmed road projects, the greatest number are in the San Francisco Bay area (District 4) and the Los Angeles Basin (District 7), with 183 and 157, respectively (Table 2), which also have the most linear distance of new projects. These districts also have the largest human populations and the greatest number of housing units. However, 9 of the 12 districts have the greatest habitat impacts for at least 1 of the 55 landcover types, and Caltrans District 3, in the northern Central Valley and Sierra Nevada, has the highest level of impacts on a maximum eight habitat types (Table 3 ).

Of an approximate 40,833,352 ha in California, 11,475 ha is estimated to be impacted by programmed highway projects (Table 3). Impacts to urban (4086 ha) and agriculture (2572 ha) lands are the largest. Among natural habitat types, annual grasslands and desert scrub are the most impacted, at 1716 and 981 ha, respectively. Other habitat types with $>1 \mathrm{~km}^{2}$ estimated impacts are blue oak woodland, coastal scrub, sagebrush, mixed chaparral, montane hardwood, and alkali desert scrub. Six habitat types are not forecast to have any impacts from these road construction activities. Caltrans Districts 6 (the San Joaquin Valley) and 4 (the San Francisco Bay Area) are projected to have the most impacts, with 2073 and 1565 ha of forecast impacts, respectively.

A total of 381 federal- or state-listed threatened, endangered, or rare species (132 vertebrates and 248 plants) have range maps that intersect watersheds containing 
Fig. 3 The interface to the California state mitigation needs database. This interface permits the user to select the geographic area to query and the type of report to generate. The coarsestscale watershed units (Hydrologic Region) are not included in the interface
frmWS : Form

$\square \square$
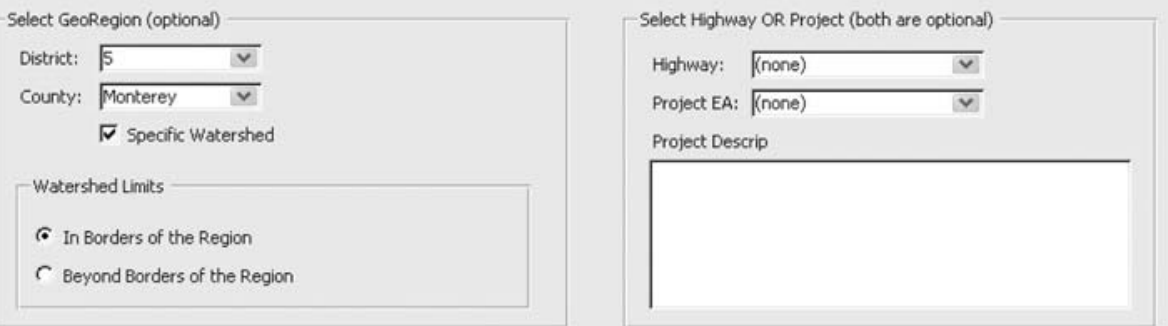

programmed projects. Of these, 114 species have recorded occurrences within the watersheds containing the 967 programmed projects in the state, and 104 species have recorded occurrences within $500 \mathrm{~m}$ of a project. District 4 has the highest number of species, 91, whose ranges intersect watersheds containing programmed projects and 57 species recorded within $500 \mathrm{~m}$ of its 183 programmed project footprints. Districts 1 (North Coast) and 9 (South East Sierra) have the lowest number (5) of species known to occur within $500 \mathrm{~m}$ of programmed projects.

Table 2 The extent of programmed projects, length of major road categories, number of housing units, and population size of the 12 Caltrans districts and the whole state of California

\begin{tabular}{|c|c|c|c|c|c|c|c|c|c|}
\hline & $\begin{array}{l}\text { Area } \\
\left(\mathrm{km}^{2}\right)\end{array}$ & $\begin{array}{l}\text { No. of } \\
\text { programmed } \\
\text { projects }\end{array}$ & $\begin{array}{l}\text { Programmed } \\
\text { projects } \\
(\mathrm{km})\end{array}$ & $\begin{array}{l}\text { Interstate } \\
\text { highways } \\
(\mathrm{km})\end{array}$ & $\begin{array}{l}\text { Federal } \\
\text { highways } \\
(\mathrm{km})\end{array}$ & $\begin{array}{l}\text { State } \\
\text { highways } \\
(\mathrm{km})\end{array}$ & $\begin{array}{l}\text { Unknown } \\
\text { type }(\mathrm{km})\end{array}$ & $\begin{array}{l}\text { No. house } \\
\text { units }\end{array}$ & Population \\
\hline Statewide & 408,509 & 967 & 6,257 & 4,178 & 2,850 & 17,890 & 3,262 & $12,020,981$ & $33,395,716$ \\
\hline District 1 & 24,451 & 42 & 274 & 0 & 524 & 992 & 256 & 126,081 & 280,700 \\
\hline District 2 & 72,264 & 71 & 324 & 315 & 409 & 2,095 & 93 & 151,568 & 339,510 \\
\hline District 3 & 32,766 & 105 & 498 & 484 & 187 & 1,789 & 317 & 903,210 & $2,259,233$ \\
\hline District 4 & 18,264 & 178 & 971 & 550 & 281 & 1,483 & 381 & $2,506,713$ & $6,668,474$ \\
\hline District 5 & 28,548 & 94 & 503 & 0 & 443 & 1,455 & 126 & 480,427 & $1,327,400$ \\
\hline District 6 & 58,417 & 86 & 702 & 311 & 57 & 2,996 & 517 & 693,641 & $2,062,735$ \\
\hline District 7 & 15,001 & 157 & 1,114 & 537 & 136 & 1,220 & 503 & $3,480,951$ & $10,166,558$ \\
\hline District 8 & 70,984 & 76 & 760 & 1,065 & 300 & 1,753 & 299 & $1,173,187$ & $3,225,110$ \\
\hline District 9 & 34,597 & 19 & 249 & 0 & 513 & 719 & 87 & 20,411 & 30,341 \\
\hline District 10 & 28,574 & 93 & 430 & 227 & 0 & 1,909 & 510 & 480,424 & $1,357,218$ \\
\hline District 11 & 22,583 & 56 & 297 & 571 & 0 & 1,119 & 129 & $1,064,141$ & $2,908,650$ \\
\hline District 12 & 2,060 & 44 & 139 & 117 & 0 & 360 & 46 & 940,227 & $2,769,787$ \\
\hline
\end{tabular}

Note: Some projects occur in more than one district 


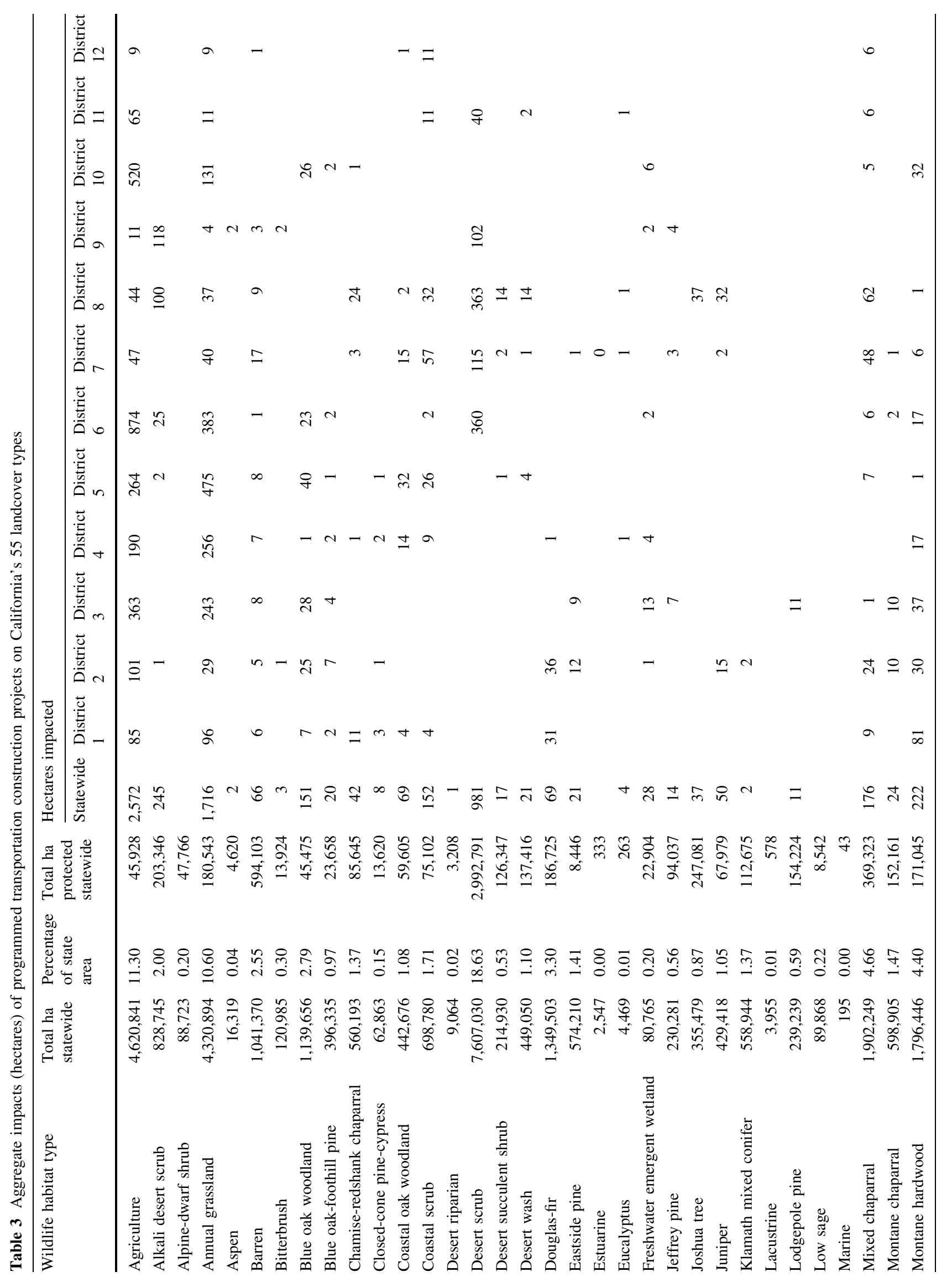




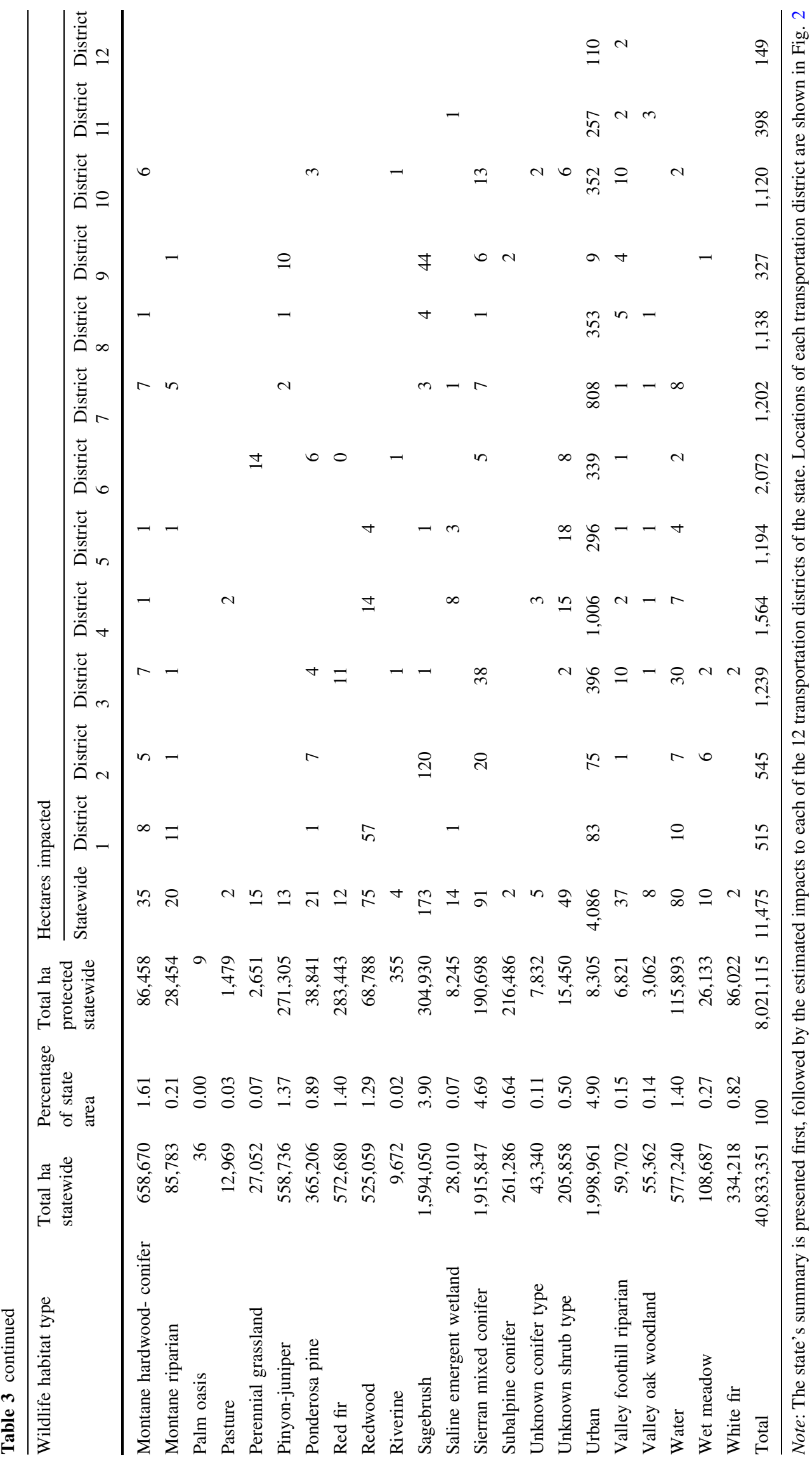


Specific Watershed

The Salinas River covers $9135 \mathrm{~km}^{2}$ and contains 140,516 housing units and 429,762 people. There are 21 programmed projects in the Salinas watershed, with projected impacts of 162.7 ha, including 1 ha of coastal scrub, 8.3 ha of coast live oak woodland, and 0.06 ha of saline emergent wetland. More than 56 ha of the impacts are in urban areas, 43 ha in agricultural lands, and 43 ha on annual grasslands. There are 18 federally or state-listed vertebrate species and 28 listed plant species whose range maps intersect the watershed. Of those 46 listed species, there are georeferenced locations for 13 species within subwatersheds containing the projects, and 2 (Gilia tenuiflora ssp. arenaria and Vuples macrotis mutica) are within $500 \mathrm{~m}$ of programmed projects.

\section{Specific Highway}

Highway 132 is $122 \mathrm{~km}$ long and runs east-west between Modesto and Freemont in California's San Joaquin Valley (Fig. 3, inset) and has four programmed projects. Sixteen landcover types occur within $500 \mathrm{~m}$ of the highway, covering 12,152 ha, of which 68.4 ha would be impacted. Urban (50.1 ha) and agriculture (16.5 ha) will be the most impacted landcover types. Three natural vegetation types will be impacted: annual grasslands ( 0.9 ha) and two sensitive habitats, valley foothill riparian ( $0.6 \mathrm{ha})$, and freshwater emergent wetlands $(0.1 \mathrm{ha})$. The report also includes the overall extent of each landcover type in the state, e.g., freshwater emergent wetlands cover 184,921 ha, of which $17 \%$ or 32,141 ha is currently protected, a low number for the high ecological value of this habitat. Three of the four projects programmed on Highway 132 are along the edges of urban areas, leading to the high level of urban impacts.

There are 14 listed terrestrial vertebrates and 23 listed vascular plants whose ranges fall in watersheds that intersect this highway. Sixteen listed species have georeferenced records within the project's watersheds, of which one, Swainson's hawk (Buteo swainsoni), was recorded within $500 \mathrm{~m}$ of the programmed projects along the highway.

\section{Discussion}

Agencies with long-term planning horizons are in a unique situation. They have the potential to assess and quantify some their mitigation needs early, and for multiple sites, which can lead to more biologically effective and cheaper mitigation solutions. A major challenge is successful identification of projected aggregate environmental impacts (Lawrence 2007), which could permit mitigation plans acceptable to regulatory agencies (Brown 2006; Hardy 2007). We showed that a GIS database approach could summarize road construction impacts to 55 landcover types and 177 listed plant and animal species, and that the results can be reported for different eight spatial representations of California.

The database developed for this study was intended to provide state transportation planners and transportation agency biologists with a simple tool for forecasting their cumulative mitigation needs. Once the data were integrated in the GIS, a database was developed that allowed the cross-querying of the biological resources, programmed projects, and spatial domains. The result was a capacity to estimate the mitigation obligations for programmed projects in any combination of the watershed and administrative units in the database. This multiscale framework permits spatially flexible summations of results between the 967 programmed projects, depending on the questions being asked. For example, an environmental impact biologist could use the database to preview what species might be encountered before heading out to the field for a survey of a project site, while an environmental planner could use it to assess the overall magnitude of mitigation obligations for habitat impacts in a watershed, transportation planning district, or highway (Fig. 1). This type of multiscale forecasting capacity will make it easier to justify the acquisition of projected impacted habitat types for mitigation at an early phase of the planning process, when acquisition of the property is more logistically and fiscally feasible. In some cases early acquisition may be the only option, because waiting could lead to no habitat remaining available for acquisition.

Caltrans' long planning horizon provided an opportunity for an aggregate impact forecast. We were able to quantify the footprints of funded highway projects and assess their habitat- and species-level impacts. From a regional planning perspective, these results represent a first step or contribution to an overall accounting, which could eventually also include other development impacts to the same habitat types. This was one of the advantages of using a defined set of spatial domains for the database architecture; defined spatial domains permit easy incorporation of other impacts in any given planning unit into an overall analysis. This approach can help mitigation planning to better contribute to the broader goal of systematic conservation planning (Mattson and Angermeier 2007; Margules and Pressey 2000).

Measures of other impacts that could be incorporated include landscape fragmentation indexes such as effective mesh size (Jaeger 2000; Moser and others 2007; Girvetz and others 2008), which could provide further context on the level of habitat degradation in various planning units. Additionally, spatially explicit models of expected urban 
growth (Johnston and others 2003; Thorne and others 2006a; Landis 1995), its attendant transportation requirements, and its associated water quality impacts could be added to the framework. However, since the location of future urban growth is less centrally planned than that of road infrastructure, urban growth would need to use a model-based approach, such as the rule-based and geographical urban growth simulation modeling program UPlan (Johnston and others 2003). Expected shifts in dominant vegetation under climate change (Lenihan and others 2003) could potentially also be integrated, although model spatial scale output is coarse, and there are multiple futures scenarios. These types of information (future urban growth and climate change impacts) could be used both to assess the possibility that a site will impacted by multiple effects (including roads) and to assess the long-term viability of proposed mitigation sites.

In terms of biological resources, there are a number of other types of information that could be included in this database structure. Regional conservation plans and/or wildlife connectivity models that identify target areas for preservation could be incorporated (e.g., Penrod and others 2000; Thorne and others 2006b; Shilling and others 2002; Noss and others 1999), so that transportation and other planners could know when a watershed they are working in has additional value for conservation or terrestrial connectivity. Detailed maps of species richness or hotspots are another measure of conservation importance (Myers and others 2000) that could be integrated. Air quality and stream condition data could also be incorporated, where mapped assessments are available.

The cumulative ecological impacts at a given road construction site may extend beyond the direct impacts described here. Additional impacts could include the compounding effects of multiple disturbances on processes such as species dispersal (Forman and Alexander 1998), hydrologic systems (Risser 1988), and water quality (Coats and Miller 1981). Furthermore, mitigation is not always successful (e.g., Sudol and Ambrose 2002), and may require monitoring to determine long-term success (Hierl and others 2008). However, our approach permitted quantification of some direct impacts on a per-site basis and the capacity to sum those across sites. This capacity is an advance toward the goal of a comprehensive regional assessment capability. The framework presented here identifies methods by which other assessments of cumulative impacts could be incorporated.

Besides addressing only direct impacts, another limitation of this study was the detail inherent in the landcover map used. This map (California Department of Forestry and Fire Protection 2002) identifies the dominant landcover at a 1 -ha $(100 \times 100-\mathrm{m})$ resolution. The landcover map's habitat classification system works well for identifying
California habitat types used by vertebrates. However, the map's scale means that some fine-scale, biologically important landscape elements, particularly small wetlands such as vernal pools and freshwater emergent wetlands, are missed. Therefore, these results should be treated as an approximation of expected impacts, and on-the-ground surveys are likely to identify additional impact acreage, especially for spatially restricted habitat types. Site-level surveys will likely also result in somewhat different area estimates for the widespread vegetation types reported here, but we anticipate lower result discrepancies for those types.

We developed an expandable database framework as a first step for assessing environmental impacts for transportation project mitigation forecasting in California. As such, it represents a static summary of aggregate habitat impacts. Additional work will make it possible to update the spatial database, and user modifications may eventually be possible. Such modifications could permit the incorporation of new data at a central database location, but with the new projects being loaded and queried remotely from various agency offices, as is being done in Florida with the Efficient Transportation Decision Making web site (Florida Department of Transportation 2008). In this manner, the database could be used to prescreen potential road construction projects at their earliest preprogrammed phase, leading to avoidance, the best mitigation practice of all.

This project demonstrated a technique for quantifying aggregate habitat impacts in a manner accessible to resource managers and planners. The open database structure permits easy updating as new data become available. The database framework can be adapted to address a wider range of potential impacts and a fuller accounting of natural resources as those become available, and could prove useful in other regional impact assessment and planning efforts.

Acknowledgments Funding for this publication was provided by the California Department of Transportation. Space and computers to conduct the research were provided by Dr. James F. Quinn, Director of the Information Center for the Environment, University of California, Davis.

Open Access This article is distributed under the terms of the Creative Commons Attribution Noncommercial License which permits any noncommercial use, distribution, and reproduction in any medium, provided the original author(s) and source are credited.

\section{References}

American Association of State and Highway Transportation Officials (2003) Causes and extent of environmental delays in transportation projects. American Association of State and Highway Transportation Officials, Washington, DC 
Brown JW (2006) Eco-logical: an ecosystem approach to developing infrastructure projects Office of Project Development and Environmental Review. Federal Highway Administration, Washington, DC

Byrne M (2005) Preliminary environmental analysis report tool. California Department of Transportation, Sacramento, CA

California Department of Fish and Game, California Interagency Wildlife Task Group (2005) California Wildlife Habitat Relationships model, version 8.0. Personal computer program. California Department of Fish and Game, Sacramento, CA

California Department of Fish and Game, Wildlife and Habitat Data Analysis Branch (2006) California natural diversity database. California Department of Fish and Game, Sacramento, CA

California Department of Forestry and Fire Protection (2002) FRAP multi-source vegetation map. California Department of Fish and Game, Sacramento, CA

California Department of Forestry and Fire Protection (2004) California counties. California Department of Forestry and Fire Protection, Sacramento, CA

California Department of Transportation (2006) Caltrans districts GIS. California Department of Transportation, Sacramento, CA

California Interagency Watershed Mapping Committee (2004) California Interagency Watershed map (CalWater), v2.2.1. State of California Department of Water Resources, Sacramento, CA

Coats RN, Miller TO (1981) Cumulative silvicultural impacts on watersheds - a hydrologic and regulatory dilemma. Environmental Management 5:147-160

Dale V, Archer S, Chang M, Ojima D (2005) Ecological impacts and mitigation strategies for rural land management. Ecological Applications 15:1879-1892

Environmental Law Institute (2006) 2005 status report on compensatory mitigation in the United States. Environmental Law Institute, Washington, DC

ESRI (2006) ArcGIS 9.2 software. ESRI, Redlands, CA

Florida Department of Transportation (2001) Environmental Management Office. Available at: http://fdotenvironmentalstreamlining. urs-tally.com/

Florida Department of Transportation (2008) Efficient Transportation Decision Making (ETDM) website. Available at: http://etdmpub. fla-etat.org/est/\#. Accessed online May 15, 2008

Forman R (2000) Estimate of the area affected by the road system in the United States. Conservation Biology 14:31-35

Forman RTT, Alexander LE (1998) Roads and their major ecological effects. Annual Review of Ecology and Systematics 29:207-231

Forman RTT, Sperling D, Bissonette JA, Clevenger AP, Cutshall CD, Dale VH, Fahrig L, France R, Goldman CR, Heanue K, Jones JA, Swanson FJ, Turrentine T, Winter TC (2003) Road ecology: science and solutions. Island Press, Washington, DC

Geneletti D (2006) Some common shortcomings in the treatment of impacts of linear infrastructures on natural habitat. Environmental Impact Assessment Review 26:257-267

Geographic Data Technologies (2006) Digital roads for California. Boston, MA

Girvetz EH, Thorne JH, Jaeger JA, Berry AM (2008) Integration of landscape fragmentation analysis into regional planning: a statewide multi-scale case study from California, USA. Landscape and Urban Planning 86:205-218

Hardy A (2007) Developing the integrated transportation and ecological enhancements for Montana process: applying the "Eco-logical" approach. Transportation Research Record 2011: $148-156$

Hickman JC (ed) (1993) The Jepson manual: higher plants of California. University of California Press, Berkeley

Hierl LA, Franklin J, Deutschman DH, Regan HM, Johnson BS (2008) Assessing and prioritizing ecological communities for monitoring in a regional habitat conservation plan. Environmental Management 42:165-179

Hoctor T, Carr MH, Zwick PD (2000) Identifying a linked reserve system using a regional landscape approach: the Florida ecological network. Conservation Biology 14:984-1000

Jaeger JAG (2000) Landscape division, splitting index, and effective mesh size: new measures of landscape fragmentation. Landscape Ecology 15:115-130

Johnston RD, Schabazian D, Gao S (2003) UPlan: a versatile urban growth model for transportation planning. Transportation Research Planning 183:202-209

Landis JD (1995) Imagining land use futures: applying the California urban futures model. Journal of the American Planning Association 61:438-457

Lawrence DP (2007) Impact significance determination - pushing the boundaries. Environmental Impact Assessment and Review 27: $770-788$

Lenihan JM, Drapek R, Bachelet D, Neilson RP (2003) Climate change effects on vegetation distribution, carbon, and fire in California. Ecological Applications 13:1667-1681

Levinson HS (2004) Highways, people, and places: past, present, and future. Journal of Transportation Engineering 130:406-411

Margules CR, Pressey RL (2000) Systematic conservation planning. Nature 405:243-253

Mattson KM, Angermeier PL (2007) Integrating human impacts and ecological integrity into a risk-based protocol for conservation planning. Environmental Management 39:125-138

Microsoft (2006) Access database software. Microsoft, Seattle, WA

Miller HJ (1999) Potential contributions of spatial analysis to geographic information systems for transportation (GIS-T). Geographical Analysis 31:373-399

Moser B, Jaeger JAG, Tappeiner U, Tasser E, Eiselt B (2007) Modification of effective mesh size for measuring landscape fragmentation to solve the boundary problem. Landscape Ecology 22:447-459

Munz PA (1968) Supplement to a California flora. University of California Press, Berkeley

Munz PA, Keck DD (1959) A California flora. University of California Press, Berkeley

Myers N, Mittenmeier RA, Mittenmeier CG, da Fonseca GAB, Kent J (2000) Biodiversity hotspots for conservation priorities. Nature 403:853-858

National Academy of Sciences (2001) Compensating for wetland losses under the Clean Water Act. National Academies Press, Washington, DC

National Academy of Sciences (2005) Assessing and managing the ecological impacts of paved roads. National Academies Press, Washington, DC

Noss RF, Strittholt JR, Vance-Borland K, Carroll C, Frost F (1999) A conservation plan for the Klamath Siskiyou Ecoregion. Natural Areas Journal 19:392-411

O’Neill RV, Hunsaker CT, Jones KB, Riitters KH, Wickham JD, Schwartz PM, Goodman IA, Jackson BL, Baillargeon WS (1997) Monitoring environmental quality at the landscape scale: using landscape indicators to assess biotic diversity, watershed integrity, and landscape stability. BioScience 47:513-519

Penrod K, Hunter R, Merrifield M (2000) Missing linkages: restoring connectivity to the California landscape. California Wilderness Coalition, Davis

Possingham HP, Wilson KA, Andelman SJ, Vynne CH (2006) Protected areas: goals, limitations and design. In: Groome MJ, Meffe GK, Carroll CR (eds) Principles of conservation biology, 3rd edn. Sinauer Associates, Sunderland, MA, pp 509-533

Risser PG (1988) General concepts for measuring cumulative impacts on wetland ecosystems. Environmental Management 12:585-589 
Sarkar S, Pressey RL, Faith DP, Margules CR, Fuller T, Stoms DM, Moffett A, Wilson KA, Williams KJ, Williams PH, Andelman S (2006) Biodiversity conservation planning tools: present status and challenges for the future. Annual Review of Environment and Resources 31:123-159

Shilling FM, Girvetz EH, Erichsen C, Johnson B (2002) A guide to wildlands conservation in the Greater Sierra Nevada Bioregion. California Wilderness Coalition, Davis

Sudol MF, Ambrose RF (2002) The US Clean Water Act and habitat replacement: evaluation of mitigation sites in Orange County, California, USA. Environmental Management 30:727-734

Thorne JH, Gao S, Hollander AD, Kennedy JA, McCoy M, Johnston RA, Quinn JF (2006a) Modeling potential species richness and urban buildout to identify mitigation sites along a California highway. Transportation Research Part D 11:277-291

Thorne JH, Cameron D, Quinn JF (2006b) A conservation design for the Central Coast of California and the evaluation of mountain lion as an umbrella species. Natural Areas Journal 26:137-148
Treweek J, Vietch N (1996) The potential application of GIS and remotely sensed data to the ecological assessment of proposed new road schemes. Global Ecology and Biogeography Letters 5:4-5

U.S. Census Bureau (2000) United States Census 2000. U.S. Department of Commerce, Economics and Statistics Administration, Washington, DC

U.S. Congress (1969) National Environmental Policy Act. U.S. Congress, Washington, DC

U.S. Congress (1973) Section 10. US Endangered Species Act.. U.S. Congress, Washington, DC

U.S. Congress (2005) Safe, Accountable, Flexible, Efficient Transportation Equity Act (SAFETEA-LU). U.S. Congress, Washington, DC

Viers JH, Thorne JH, Quinn JF (2006) CalJep: a spatial distribution database of CalFlora and Jepson plant species. San Francisco Estuary and Watershed Science 4:1-18. Available at: http://repositories. cdlib.org/jmie/sfews/vol4/iss1/art1 